\title{
A Model for Improving E-Tax Systems Adoption in Rural Zambia Based on the TAM Model
}

\author{
Patience Njina Soneka ${ }^{1}$, Jackson Phiri ${ }^{2}$ \\ ${ }^{1}$ Graduate School of Business, University of Zambia, Lusaka, Zambia \\ ${ }^{2}$ Department of Computer Sciences, School of Natural Sciences, University of Zambia, Lusaka, Zambia \\ Email: sonekapn@yahoo.com, jackson.phiri@cs.unza.zm
}

How to cite this paper: Soneka, P.N. and Phiri, J. (2019) A Model for Improving E-Tax Systems Adoption in Rural Zambia Based on the TAM Model. Open Journal of Business and Management, 7, 908-918. https://doi.org/10.4236/ojbm.2019.72062

Received: March 22, 2019

Accepted: April 20, 2019

Published: April 23, 2019

Copyright () 2019 by author(s) and Scientific Research Publishing Inc. This work is licensed under the Creative Commons Attribution International License (CC BY 4.0).

http://creativecommons.org/licenses/by/4.0/

\section{(c) (i) Open Access}

\begin{abstract}
The objective of this study was to assess the factors that influence the level of e-tax systems adoption in Zambia. The study focused on TaxOnline system used by domestic taxes division in Zambia. The study was conducted in rural Zambia. In this study, the researcher used Technology Acceptance Model (TAM). The sample size was purposively selected from various taxpayers who were coming through to Zambia Revenue Authority Solwezi internet bureau. 100 semi structured survey questionnaires were distributed with $100 \%$ response. The data collected was analyzed using descriptive statistics. The results showed that, E-tax system in Zambia is useful, easy to use and also secure. Based on the findings, majority of the taxpayers are filing their returns and paying taxes online. However, there are few taxpayers who still feel E-tax is not useful, easy to use and secure. Therefore, more awareness and taxpayer education must continue to bring everyone on board. E-Tax involves E-Filing and E-Payment which is the process of submitting returns over the internet using an approved E-Tax system. Adoption is the action or fact of choosing to take up or follow something. Technology Acceptance Model is an information system theory that models how users come to accept and use a technology. TaxOnline is a system used in Zambia to file returns and pay taxes online.
\end{abstract}

\section{Keywords}

E-Tax, Adoption, Technology Acceptance Model, TaxOnline, E-Payment, Rural Zambia

\section{Introduction}

Internet and its related technology applications are increasingly popular for business organization and public institutions [1]. Governments around the 
world are increasing the use of information and communication technologies (ICTs) to improve the delivery of services and dissemination of information to the public [2]. E-tax system introduction was as a result of the emergence of information technology to improve the level of tax compliance without the physical appearance at the tax office not having contact with the tax officers when filing their tax return [3]. E-tax services are important applications that enable citizens to file taxes online [4]. Wang also stated that E-tax improves accuracy and efficiency over paper-based filing and lower costs. In Zambia, E-tax (tax online) was introduced in October, 2013 [5].

\section{Literature Review}

Throughout the world, revenue authorities in conjunction with their governments have worked hard to come up with E-tax systems for easy tax administration. This section of the literature looks at Taxation and E-tax system adoption. E-filing is one of the most important and advanced e-government services in Malaysia, providing convenience to taxpayers for tax assessments and payment [6]. Electronic Government (e-Government) has long been sounding as a breakthrough of communication and transaction between the government and citizens. It is not only to help government to accomplish daily administrative activities but also to provide more easy way to communicate with external entities such as citizens and businesses throughout the utilization of information technology [7]. In fact, e-Government is the use of technology web-based applications in order to enhance access to and efficiently deliver government information and services [8]. Its sole purpose is to provide information and assistance to the citizens including links to renew a passport, download visa forms [9].

In recent times, one prominent type of e-Government services has been the introduction of the e-filing system for income tax, commonly known as the e-Tax services. Through this system, taxpayers are able to submit their tax returns electronically to the proper government authorities by preparing, reporting and paying their taxes online [10]. The E-Tax service has been implemented with the goal of easing the burden on the taxpayer and increase compliance of tax filing through the innovative use of technology [9]. Administratively, e-Tax offers a potential benefit to the government through e-Government. This is considered as one of the breakthrough of communication and transaction between the government and citizens. It is not only to help government to accomplish daily administrative activities but also to provide more easy way to communicate with external entities such as citizens and businesses throughout the utilization of information technology [7]. Its sole purpose is to provide information and assistance to the citizens including links to renew a passport, download visa forms [9].

In recent times, one prominent type of e-Government services has been the introduction of the e-filing system for income tax, otherwise known as the e-tax services. Through this system, taxpayers are able to submit their tax returns electronically to the proper government authorities by preparing, reporting and 
paying their taxes online [10]. The E-tax service has been implemented with the goal of easing the burden on the taxpayer and increase compliance of tax filing through the innovative use of technology [9]. Administratively, E-tax offers a potential benefit to the government as well because the process of tax return by the citizens can now be managed effectively via the enabling of technologies [11]. In recent times, one prominent type of e-Government services has been the introduction of the e-filing system for income tax, otherwise known as the E-tax services. Through this system, taxpayers are able to submit their tax returns electronically to the proper government authorities by preparing, reporting and paying their taxes online [10]. The E-tax service has been implemented with the goal of easing the burden on the taxpayer and increase compliance of tax filing through the innovative use of technology [9]. Administratively, E-tax offers a potential benefit to the government as well because the process of tax return by the citizens can now be managed effectively via the enabling of technologies. The E-tax service is thus an important application that automates tax related processes in an attempt to improve efficiency in assessing and collecting tax information. It has the potential to improve tax-filing service while at the same time reducing costs to both taxpayers and tax collecting agencies [11].

Generally, such a service has been initiated by the government in many developed and developing countries in order to improve information flow and processes, along with the speed and quality of policy development, coordination and enforcement related to income tax filing. It has enabled many governments to become more responsive to the needs of its citizens, ultimately resulting in less corruption, increased transparency, greater convenience, revenue growth and/or cost reductions [8]. Although the adoption of e-Tax filing is potentially a route to the provision of better services delivered to citizens at a lower cost, there is a low level of acceptance or adoption of such services in many developing countries even today [12]. The benefits of e-tax services are linked to its adoption and usage [13].

\subsection{E-Tax System in Zambia}

The implementation of E-tax in Zambia by the Zambia Revenue Authority started in 2013 [5]. In order to make tax administration easier and less costly for both the taxpayer and the tax collector, Zambia Revenue Authority continued to roll new and robust ICT and business system namely Tax online and ASYCUDA world, which cover the administration of domestic and trade taxes, respectively. These systems are web based thus enabling the taxpayers to access them on a 24 hours basis from anywhere with internet connection [5].

\subsection{TaxOnline Return Filling Status Report for North-Western Province}

Figure 1 and Figure 2 highlights the methods used by taxpayers to file in returns in 2013 and 2018 respectively as generated from the Zambia Revenue Authority TaxOnline system. It shows that the manual filing has reduced while the 
e-returns filing has increased. The trend highlights how well the e-tax system is being adopted.

\subsection{Technology Acceptance Model (TAM)}

The Technology Acceptance Model (TAM) is an information systems theory that models how users come to accept and use a technology as shown in Figure 3. The model suggests that when users are presented with a new technology, a number of factors influence their decision about how and when they will use the technology.

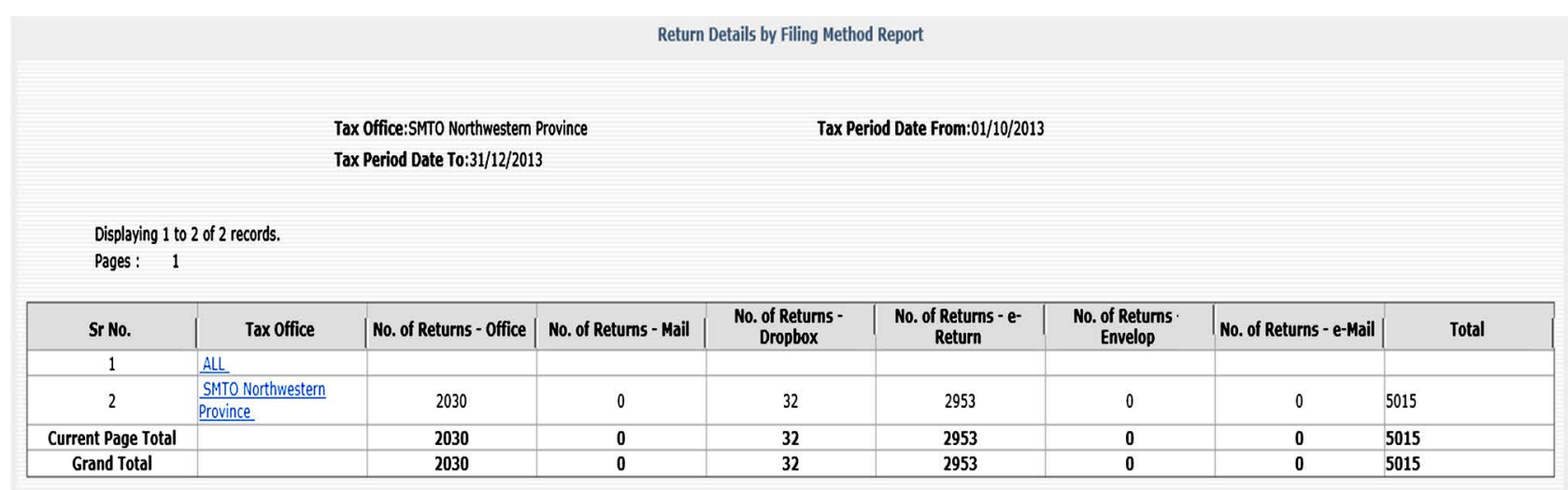

Figure 1. Methods used by taxpayers to submit returns in 2013.

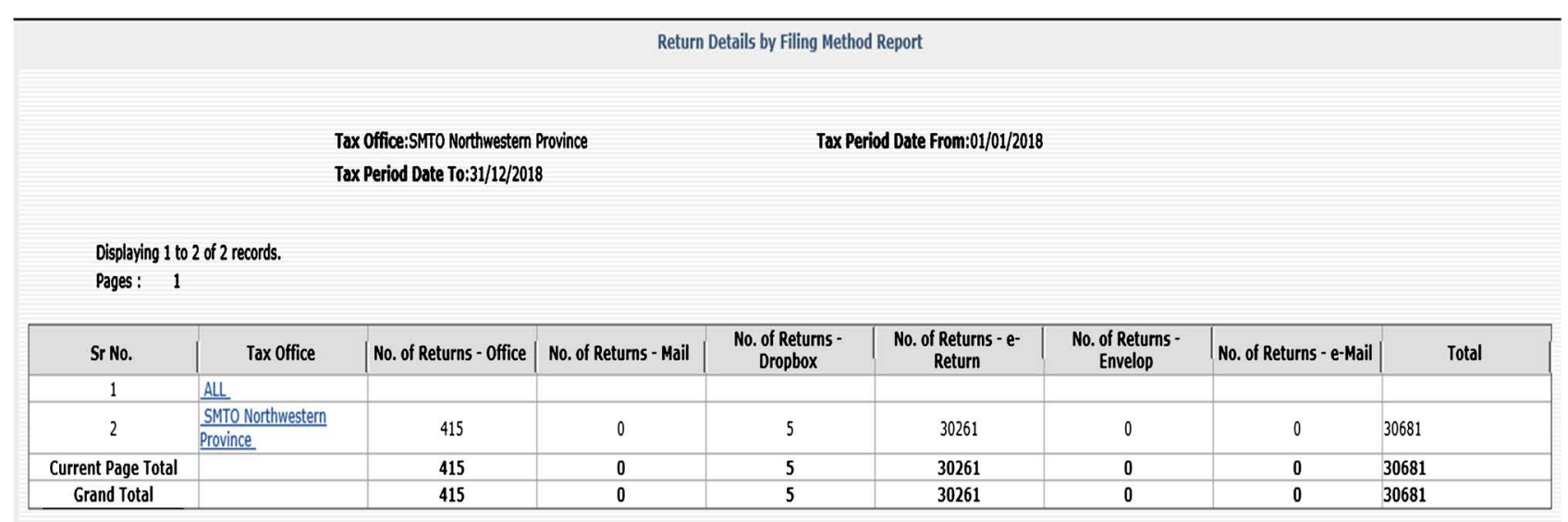

Figure 2. Methods used by taxpayers to submit returns in 2018.

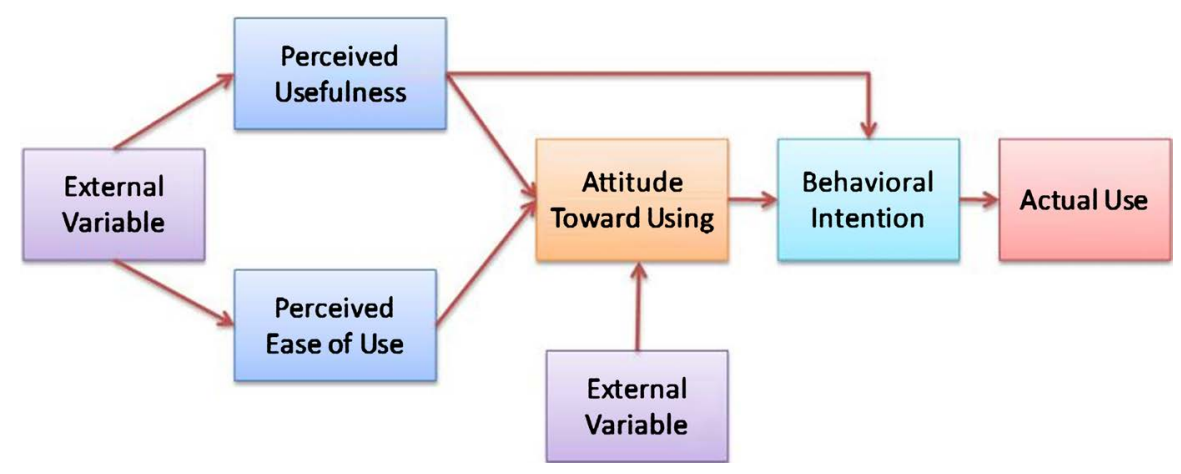

Figure 3. Technology acceptance model [13]. 
The key factors include [14];

- Perceived usefulness (PU) - This was defined by Fred Davis as "the degree to which a person believes that using a particular system would enhance his or her job performance".

- Perceived ease-of-use (PEOU)-Davis defined this as "the degree to which a person believes that using a particular system would be free from effort".

\section{Methodology}

This study used descriptive and quantitative survey design [15] [16]. According to [17], quantitative research often translates into the use of statistical analysis to make the connection between what is known and what can be learned through research, whereas qualitative is defined as a study which is conducted in a natural setting [16]. Qualitative research approach will provide an enquiry for understanding a social or human problem based on building a complex, holistic picture, formed with words, reporting detailed views of information and conducting it in a natural environment.

Population refer is the aggregate or totality of all objects, subjects or members that conform to a set of specifications [18]. Population can also be defined as the total number of units from which data can be collected", such as individuals, artifacts, events or organizations.

In this study, the population comprised of taxpayers who are based in rural and remote town called Solwezi the capital of the North-Western Province of Zambia. At the time of the research, the population was 4593 of active taxpayers. The sample was purposively selected from various taxpayers that walked in Solwezi Zambia Revenue Authority internet bureau. The sample size was determined by using the formula;

$$
n=N / 1+N\left(\mathrm{e}^{2}\right)
$$

Equation (1) was used to determine the sample size, where $\mathrm{n}$ is the sample size, $\mathrm{N}$ is the population and e is the level of precision. Based on $10 \%$ precision level, it gave a sample size of 99. A total of 100 questionnaires were distributed and we had $100 \%$ response rate.

Primary data was collected by use of a semi-structured questionnaire. Secondly data was obtained from literature review of similar studies.

The study used SPSS to analyze data collected. The Pearson correlation coefficient and P-values were used to in the statistical analysis of the results.

Figure 4 shows the model adapted from the TAM model in Figure 3 that was used in this study. It highlights the relationship between the three variables; perceived usefulness, perceived ease of use and perceived risk to E-tax adoption. In this study, these three variables were used to explain how these variables affect the adoption of E-tax system in rural Zambia.

\section{Results}

In this section, the basic statistical results are heighted. Based on Figure 4 adapted 
from TAM, we highlight the correlation and p-value of results. We begin with the bio data and demographics of respondents.

\subsection{Basic Statistical Analysis}

Table 1 shows gender distribution of the respondents. Among the respondents $48 \%$ were male and $52 \%$ were female.

Figure 5 shows internet experience in years. Internet experience has an effect on the adoption of E-tax system; the more people are experienced with internet, the more likely that people will find it easy to adopt an E-tax system. Among the respondents, the majority $30 \%$ had no internet experience which followed by those who had 1 - 3 years internet experience which represented $25 \%$ of the sample size and the least were those with computer experience of less than one

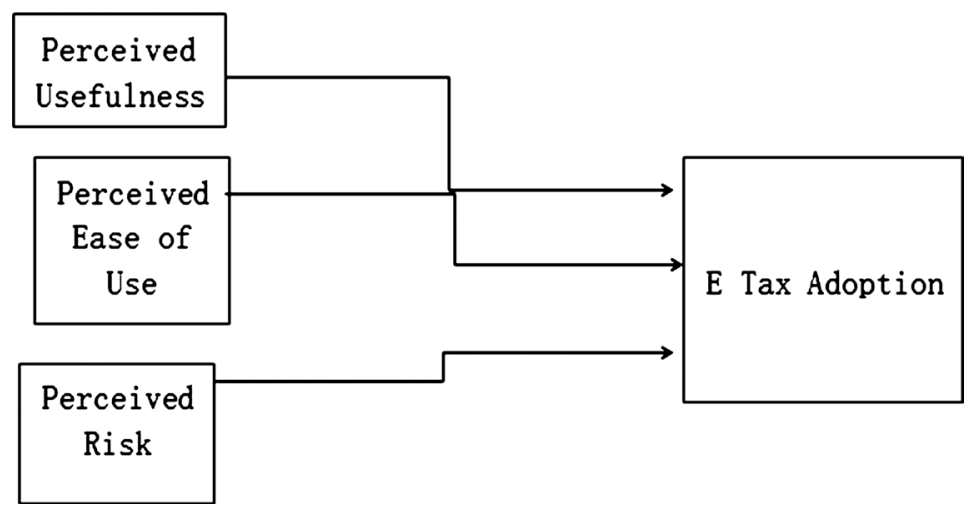

Figure 4. Research Model devoloped in this study.

Table 1. Gender distribution of respondents.

\begin{tabular}{rcccc}
\hline & Gender & Percent & Valid Percent & Cumulative Percent \\
\hline Male & 48 & 48 & 48 & 48 \\
Female & 52 & 52 & 52 & 52 \\
Total & 100 & 100 & 100 & 100
\end{tabular}

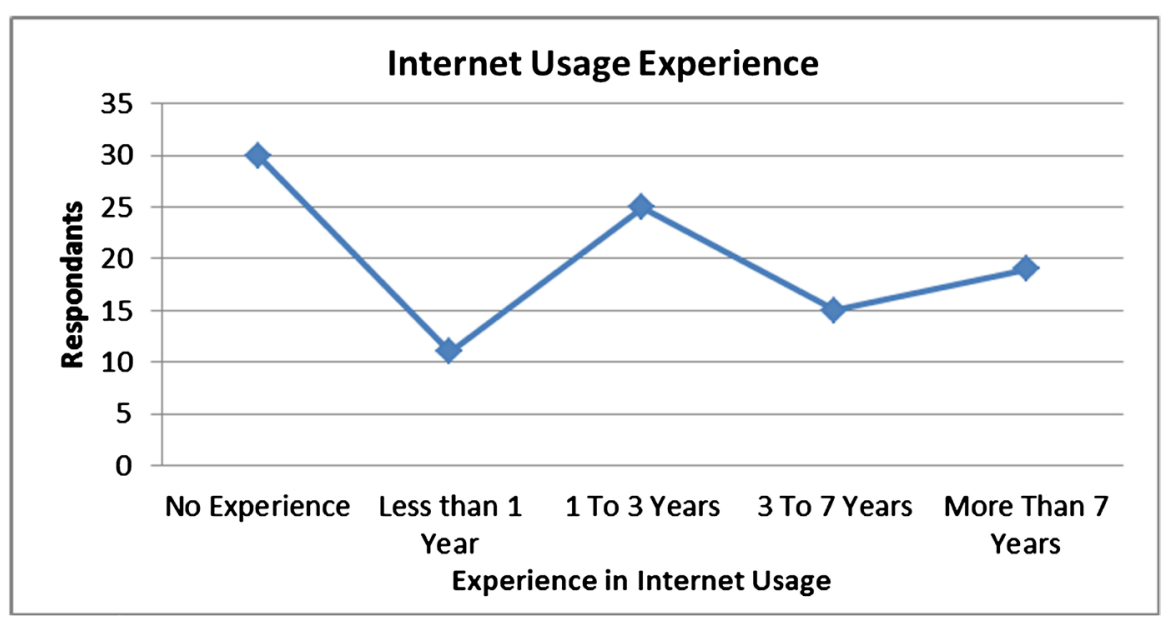

Figure 5. Internet experience in years. 
year which represented $11 \%$.

\subsection{Statistical Analysis Based on Technological Acceptable Model}

The Technology Acceptance Model (TAM) is an information systems theory that models how users come to accept and use a technology. The model suggests that when users are presented with a new technology, a number of factors influence their decision about how and when they will use technology. In this study we look at the following factors; Perceived Usefulness, Perceived Ease of Use and Risk. The statistical analysis results based on these three factors are as follows:

Table 2 shows responses of how useful TaxOnline is. The majority $63 \%$ indicated that TaxOnline is useful to them, while $25 \%$ felt it is not useful and $12 \%$ were not sure.

Among the reasons cited by those who felt that TaxOnline has been useful were that; it is affordable to file returns using TaxOnline, it is convenient, saves time and money.

Table 3 shows responses on how ease TaxOnline has been to use. The majority $65 \%$ indicated that Tax online is useful to them, while $28 \%$ felt it is not useful and $7 \%$ were not sure.

Table 4 shows responses on how secure TaxOnline is. The majority $62 \%$ indicated that TaxOnline is secure to use, while $27 \%$ felt it is not secure to

Table 2. Usefulness of TaxOnline.

\begin{tabular}{ccccc}
\hline & Frequency & Percent & Valid Percent & Cumulative Percent \\
\hline Yes & 63 & 63 & 63 & 63 \\
No & 25 & 25 & 25 & 25 \\
Not Sure & 12 & 12 & 12 & 12 \\
Total & 100 & 100 & 100 & 100 \\
\hline
\end{tabular}

Table 3. Ease of use of TaxOnline.

\begin{tabular}{ccccc}
\hline & Frequency & Percent & Valid Percent & Cumulative Percent \\
\hline Yes & 65 & 65 & 65 & 65 \\
No & 28 & 28 & 28 & 28 \\
Not Sure & 7 & 7 & 7 & 7 \\
Total & 100 & 100 & 100 & 100
\end{tabular}

Table 4. Security of filing returns using TaxOnline.

\begin{tabular}{ccccc}
\hline & Frequency & Percent & Valid Percent & Cumulative Percent \\
\hline Yes & 62 & 62 & 62 & 62 \\
No & 27 & 27 & 27 & 27 \\
Not Sure & 11 & 11 & 11 & 11 \\
Total & 100 & 100 & 100 & 100 \\
\hline
\end{tabular}


use and $11 \%$ were not sure. When a system is secure, it means it is less risky and taxpayers felt safe to use it.

Among the reasons cited by those who felt that TaxOnline is secure to use were that; the system prompts and allows them to change password from time to time.

Table 5 shows the main reasons for using TaxOnline. The majority $28 \%$ indicated that TaxOnline Saves time, while $25 \%$ indicated that its convenience and $23 \%$ felt that it saves time.

\subsection{Data Correlation and P-Values Based on TAM Model}

Figure 6 shows the results analysis using Pearson Correlation Coefficient and P-values based on the TAM in Figure 3. From the Pearson Correlation coefficient the Multiple R value is 0.99795 while P-value of 0.0407 to four decimal places.

\section{Discussion}

\subsection{Correlation Coefficient}

Figure 6 highlights the Pearson correlation and p-values for the variables used

Table 5. Main reasons for using TaxOnline.

\begin{tabular}{ccccc}
\hline & Frequency & Percent & Valid Percent & Cumulative Percent \\
\hline Save Time & 60 & 28 & 28 & 28 \\
Save Money & 50 & 23 & 23 & 23 \\
Convenience & 54 & 25 & 25 & 25 \\
No Other Option & 16 & 7 & 7 & 7 \\
Not Sure & 36 & 17 & 17 & 17 \\
Total & 216 & 100 & 100 & 100 \\
\hline
\end{tabular}

SUMMARY OUTPUT FOR PEARSON CORRELLATION COEFFICIENT AND P-VALUES

\begin{tabular}{|c|c|c|c|c|c|c|c|c|c|}
\hline \multicolumn{2}{|c|}{ Regression Statistics } & & Useful & Ease To Use & Secure & & Useful & Ease To Use & Secure \\
\hline Multiple R & 0.997956613 & & 1 & & & & 63 & 65 & 62 \\
\hline R Square & 0.995917402 & & 0.993063 & 1 & & & 25 & 28 & 27 \\
\hline Adjusted R Square & 0.991834805 & & 0.997957 & 0.998546619 & 1 & & 12 & 7 & 11 \\
\hline Standard Error & 2.394721044 & & & & & & & & \\
\hline Observations & 3 & & & & & & & & \\
\hline \multicolumn{10}{|l|}{ ANOVA } \\
\hline & $d f$ & SS & MS & $F$ & Significance $F$ & & & & \\
\hline Regression & 1 & 1398.931978 & 1398.932 & 243.9420878 & 0.040704682 & & & & \\
\hline Residual & 1 & 5.734688878 & 5.734689 & & & & & & \\
\hline \multirow[t]{2}{*}{ Total } & 2 & 1404.666667 & & & & & & & \\
\hline & Coefficients & Standard Error & t Stat & P-value & Lower 95\% & Upper 95\% & Lower 95.0\% & Upper $95.0 \%$ & \\
\hline Intercept & -0.465458109 & 2.567970161 & -0.18126 & 0.885848637 & -33.09461273 & 32.1637 & -33.09461273 & 32.16369651 & \\
\hline Variables & 1.013963743 & 0.064920082 & 15.61865 & 0.040704682 & 0.189075894 & 1.838852 & 0.189075894 & 1.838851593 & \\
\hline
\end{tabular}

Figure 6. Research results analysis using Pearson correlation coefficient and P-values. 
in this research; Perceived usefulness, Perceived ease of use and perceived risk. In statistics, the correlation coefficient $r$ measures the strength and direction of a linear relationship between two variables on a scatterplot. The value of $r$ is always between +1 and -1 . To interpret its value, see which of the following values your correlation $r$ is closest to as shown in Table 6 .

Table 6 shows the correlation Coefficient. From this study it shows that the correlation coefficient( $r)$ is $0.9979(r=0.9979)$ as shown in Figure 6 which indicates a stronger positive statistical relationship between usefulness, ease of use and risk.

\subsection{Statistical Significant (P-Values)}

All hypothesis tests ultimately use a P-value to weigh the strength of the evidence (what the data is telling you about the population). The P-value is a number between 0 and 1 and interpreted in the following way:

- A small P-value (typically $\leq 0.05$ ) indicates strong evidence against the null hypothesis, so you reject the null hypothesis.

- A large P-value (>0.05) indicates weak evidence against the null hypothesis, so you fail to reject the null hypothesis.

- P-values very close to the cutoff (0.05) are considered to be marginal (could go either way). Always report the p-value so your readers can draw their own conclusions.

From this study we are able to see that the $\mathrm{P}$-value is $0.0407(\mathrm{P} \leq 0.05)$ as shown in Figure 6 which indicates a significant positive statistical relationship between usefulness, ease of use and risk of $\mathrm{E}$ tax system.

\section{Recommendation}

The study revealed that the level of E-Tax system (TaxOnline) adoption in rural Zambia is on the higher side though there is need to continue sensitizing and educating taxpayers for them to appreciate the usefulness of E-Tax system and adopt it fully. The research results showed that there is a small number of taxpayers who still perceive E-tax system (TaxOnline) not to be useful. The study showed that there is a small number of taxpayers who still perceive E-tax system

Table 6. Correlation coefficient.

\begin{tabular}{cc} 
Exactly -1 & A perfect downhill (negative) linear relationship \\
-0.70 & A strong downhill (negative) linear relationship \\
-0.50 & A moderate downhill (negative) relationship \\
-0.30 & A weak downhill (negative) linear relationship \\
0 & No linear relationship \\
+0.30 & A weak uphill (positive) linear relationship \\
+0.50 & A moderate uphill (positive) relationship \\
+0.70 & A strong uphill (positive) linear relationship \\
Exactly +1 & A perfect uphill (positive) linear relationship \\
\hline
\end{tabular}


(TaxOnline) as not Ease to use and also a few felt that E-tax System is not secure, therefore:

1) The recommendation to Zambia Revenue Authority is that they should increase the awareness on the usefulness of Tax online when it comes to electronic returns and payments and how taxpayers work will be reduced if they submit their returns electronically as opposed to manually.

2) The recommendation to Zambia Revenue Authority is that they should increase the trainings and taxpayer education on how to use TaxOnline.

3) It would also help to increase the adoption of E-Tax system (Tax online) if the system can be simplified further to accommodate those who still feel TaxOnline is complicated to use.

\section{Conclusions}

The main purpose of this study was to develop a model of improving E-Tax systems adoption in rural Zambia. In this paper, the literature review looked at E-Tax generally and in Zambia. The model used was Technology Acceptance Model (TAM). The paper adopted descriptive and quantitative survey design and used purposive sampling methods. The research revealed that the level of E-tax system (Tax online) adoption in rural Zambia is on the higher side though there is still more to be done to help taxpayers appreciate the usefulness of E-tax system and adopt it fully. It also shows a strong relationship between Ease of use, Usefulness, Risk and E-tax Adoption in rural Zambia.

This study also encountered some limitations. Limitations of the study refer to those factors of research design or methodology that can influence the interpretation or application of the findings of the study [19].

The method of sampling used was purposive sampling which is prone to the following limitations; sample may not be a representation of the population, samples are likely to be prone to errors thus limiting the generalizability of the findings. The sample size used was 100 taxpayers which could not be enough. The research was conducted in rural Zambia and focused on TaxOnline used by domestic taxes division.

\section{Acknowledgements}

The authors wish to acknowledge all those who took part in the study.

\section{Conflicts of Interest}

The authors declare no conflicts of interest regarding the publication of this paper.

\section{References}

[1] Saibon, A., Nawawi, A. and Salin, A.S.A. (2010) E-Filing Acceptance by the Individual Taxpayers, a Preliminary Analysis. Journal of Administrative Science, 13, 1-14. 
[2] Azmi, A.C. and Bee, N.G. (2010) The Acceptance of the e-Filing System by Malaysian Taxpayers: A Simplified Model. Electronic Journal of E-Government, 8, 13-22.

[3] Siti and Bojuwon (2014) Reengineering Tax Service Quality Using a Second Order Confirmatory Factor Analysis for Self-Employed Taxpayers. International Journal of Trade, Economics and Finance, 5, 429-434. https://doi.org/10.7763/IJTEF.2014.V5.410

[4] Wang, X. (2012) Factors Influence Citizen Adoption for Government E-Tax Service.

[5] Zambia Revenue Authority. Annual Report 2014.

[6] Anna, A., Azmi, C., Kamarulzam, Y. and Hamid, H.A. (2012) Perceived Risk and Adoption of Tax E-Filing. World Applied Sciences Journal, 20, 532-539.

[7] Hussein, R., Mohamed, N., Ahlan, A. and Mahmud, M. (2010) An Integrated Model on Online Tax Adoption in Malaysia. Proceedings of the European, Mediterranean and Middle Eastern Conference on Information Systems. Global Information Systems Challenges in Management, 225-248.

[8] Suki, N.M. and Ramayah, T. (2010) User Acceptance of the e-Government Services in Malaysia: Structural Equation Modeling Approach. Interdisciplinary Journal of Information, Knowledge, and Management, 5, 395-413. https://doi.org/10.28945/1308

[9] Schaupp, L.C., Carter, L. and Hobbs, J. (2009) E-File Adoption: A Study of U.S. Tax-Payers' Intentions.

[10] Azmi, A.A.C. and Kamarulzaman, Y. (2010) Adoption of Tax e-Filing: A Conceptual Paper. African Journal of Business Management, 4, 599-603.

[11] Fu, J.R., Farn, C.K. and Chao, W.P. (2006) Acceptance of Electronic Tax Filing: A Study of Taxpayer Intentions. Information \& Management, 43, 109-126. https://doi.org/10.1016/j.im.2005.04.001

[12] Carter, L. and Bélanger, F. (2005) The Utilization of e-Government Services: Citizen Trust, Innovation and Acceptance Factors. Information Systems Journal, 15, 5-25. https://doi.org/10.1111/j.1365-2575.2005.00183.x

[13] Asianzu, E. and Maiga, G. (2012) A Consumer Based Model for Adoption of E-Tax Services in Uganda.

[14] Davis, F.D. (1989) Perceived Usefulness, Perceived Ease of Use, and User Acceptance of Information Technology. MIS Quarterly, 13, 319-340. https://doi.org/10.2307/249008

[15] Smith, A.G. (2001) Applying Evaluation Criteria to New Zealand Government Websites. International Journal of Information Management, 21, 87-114.

[16] Creswell, J.W. (2013) Research Design: Qualitative, Quantitative, and Mixed Methods Approaches. 4th Edition, SAGE Publications, Thousand Oaks.

[17] Trochim, W.M.K. (2006) The Qualitative Debate. Research Methods Knowledge Base. http://www.socialresearchmethods.net/kb/qualmeth.php

[18] Polit, D.F. and Hungler, B.P. (1999) Nursing Research; Principles and Methods. Sixth Edition, Lippincott Williams \& Wilkins, Philadelphia.

[19] Yin, R. (2009) Case Study Research: Design and Methods. Sage Publications, New York. 